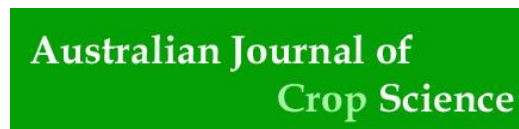

\title{
Shoot and root development of brachiaria grass (Urochloa ruziziensis) under different levels of soil density
}

\author{
Leandro Pereira Pacheco ${ }^{1 *}$, Andressa Selestina Dalla Côrt São Miguel $^{2}$, Edicarlos Damacena de \\ Souza $^{3}$, Ícaro Camargo de Carvalho ${ }^{4}$, Fabiano André Petter ${ }^{5}$, Rayane Gabriel da Silva ${ }^{6}$, Camila \\ Menezes Rodrigues da Silva ${ }^{2}$
}

${ }^{1}$ Department of Plant Science, Universidade Federal de Mato Grosso (UFMT), Rondonópolis, MT, Brazil

${ }^{2}$ Postgraduate Program in Agricultural Engineering, UFMT, Rondonópolis, MT, Brazil

${ }^{3}$ Department of Soil Science, UFMT, Rondonópolis, MT, Brazil

${ }^{4}$ Graduates in Agricultural and Environmental Engineering, UFMT, Rondonópolis, MT, Brazil

${ }^{5}$ Department of Plant Science, UFMT, Sinop, MT, Brazil

${ }^{6}$ Graduates in Agronomy, Faculdade Anhanguera, Rondonópolis, MT, Brazil

*Corresponding author: leandroppacheco@gmail.com

\begin{abstract}
For mitigation of negative effects of human activities on the soil density, the use of cover crops in no-tillage system (NTS) has been strongly recommended. This study aims to evaluate the shoot and root development of Urochloa ruziziensis subjected to soil density levels in dystrophic Oxisol. The experiment was conducted in a greenhouse with a completely randomized design, with five treatments and four replications. The treatments consisted of $U$. ruziziensis submitted to five levels of soil density $(1.0,1.2,1.4,1.6$ and $1.8 \mathrm{Mg} \mathrm{m}^{-3}$ ), twenty experimental units in total. The Urochloa ruziziensis showed reduced plant height, leaf area and number of leaves with increasing soil density, resulting in morphological and physiological changes from densities higher than $1.6 \mathrm{Mg}^{-3}$. However, these results demonstrate the ability of this species to break the compacted ground and form biopores. The Oxisols value of $1.4 \mathrm{Mg} \mathrm{m}^{-3}$ is restrictive for the plant growth and development.
\end{abstract}

Keywords: No-tillage system; soil unpacking; shoot and root development

Abbreviations: NTS_no-tillage system; DBL_Dry biomass of leaves; DBS_Dry biomass of steam; SDB_Shoot dry biomass; PH_Plant height; NL_Number of leaves; LA_Leaf area; RDB_root dry biomass; TRDB_Total root dry biomass; RV_Root volume; TRV_Total root volume.

\section{Introduction}

The agricultural systems under annual crops showed intensification in the use of implements and agricultural machinery, especially those crop systems that use the second harvest cultivation in Brazilian Cerrado. Moreover, the excessive soil disturbance in conventional tillage affects even more the soil fertility (Dezordi et al., 2013). Among the negative effects, the presence of dense soil layers stands out among the most important one. It is colloquially known as "pé-de-grade", which damages the root development of crops. When the resistance of soil penetration is higher than the pressure exerted by the roots, the decrease in the root elongation rate will directly affect plants growth and development (Passioura et al., 1991). Reduction in absorption of water and essential nutrients by plant roots may occur as a result of less volume of explored soil (Sá \& Santos Junior, 2005). The other factors that may contribute to reduction of water and nutrients absorption by plant roots is the modification of the structural arrangement of the soil, by reducing the amount of macropores, oxygenation and soil water availability (Cardoso et al., 2006; Valicheski et al., 2016). These effects can also be observed as a significant reduction in crop yield (Homma, 2005).
Many crops are affected by soil compaction. In the study of Collares et al. (2008), the bean yield was affected because there was restriction of root growth and leaf area due to the compression. Leonel et al. (2007) also reported a decrease in peanut yield as the soil compaction increased. Thus, the adoption of soil management systems that improve the physical and chemical conditions of the soil is required. It may have been done by adding organic matter in the system, which leads to a higher yield.

For mitigation of soil density caused by human activities, the use of cover crops in no-tillage system (NTS) has been recommended as an alternative. In this system, the straw on the soil surface attenuates the kinetic energy of raindrops and the direct impact produced by the machinery (Rosim et al., 2012). According to Soane (1990), the straw increases the wheels contact surface and; thereby; is capable of reducing the effects of compaction on the surface layers. Furthermore, some species are considered to be able to unpack the soil, breaking the mechanical impedance that is exercised under their massive root system.

The species from Urochloa genus have potential to improve the soil physical conditions (Calonego et al., 2011a). 
The Urochloa ruziziensis species (R. Germ \& Evrard) has been studied due to its potential attributes for improving the soil physical conditions in crop systems, especially the NTS (Bonetti et al., 2015). Calonego et al. (2011b) noted that sorghum (Sorghum bicolor (L.) Moench) and U. ruziziensis are species able to break highly dense layers of soil. However, studies are required to evaluate effects of soil density on the shoot growth of $U$. ruziziensis and to determine the efficiency and performance of this plant as cover crop in the Brazilian Cerrado. Therefore, the aim of this study is to evaluate the shoot and root development of Urochloa ruziziensis subjected to different soil density levels in dystrophic Oxisol.

\section{Results and Discussion}

\section{Effect of soil density on shoot growth of U. ruziziensis}

There was effect of soil density for all morpho-physiological variables of roots and shoots of Urochloa ruziziensisis (Table 1). The total shoot dry biomass (TSDB) showed decreasing quadratic polynomial behavior, expressing the negative effect of soil compaction on plant development (Fig. 1 A). It is important to mention that this effect was intensified from the density of $1.4 \mathrm{Mg} \mathrm{m}^{-3}$. Therefore, there is an accentuated reduction in stems production by the plant, which can be demonstrated by the decreasing linear polynomial equation observed for dry biomass of stems (DBS). Silva et al. (2006) observed a significant reduction on shoot growth of Urochloa brizantha cv. Marandu from density of $1.5 \mathrm{mMMg} \mathrm{m} \mathrm{m}^{-3}$. Jimenez et al. (2008) evaluated different densities in Oxisol and found no effect of compaction for this parameter for the species: pigeon pea (Cajanus cajan), sesame (Sesamum indicum L.), millet (Pennisetum glaucum L.) cv. ADR 300 and quinoa (Chenopodium quinoa Willd).

$U$. ruziziensis presented potential on minimizing the reduction of dry biomass of leaves (DBL) when cultivated in soils with higher densities (Fig 1A). Although significant reduction was detected in the number of leaves with the increase in soil density (Fig. 1B), it was visually observed that $U$. ruziziensis had increased leaf thickness, resulting in compensation in the DBL. The results of this study are consistent with those carried out by Lima et al. (2015) who studied the $U$. ruziziensis in Oxissol, revealing that the larger number of leaves and leaf area values were observed, when cultivated in densities from 1.3 to $1.5 \mathrm{Mg} \mathrm{m}^{-3}$, showing a high capacity in biomass production. The significant reduction of the number of leaves can be explained by the lower capacity for absorbing water and nutrients from the soil, which results in the production of stress signaling (abscisic acid) and leaf morpho-physiological changes such as the deposition of hydrophobic substances in the leaf epidermis to relieve transpiration.

Bonfim-Silva et al. (2012) found a linear decrease in the biomass of leaves and stems of $U$. brizantha $\mathrm{cv}$. Marandu to the maximum density of $1.6 \mathrm{Mg} \mathrm{m}^{-3}$. By comparing the results with the present study, the $U$. ruziziensis showed less effect on the increase of soil density in the DBS and DBL. This reinforces that among the Urochloa sp. species, the $U$. ruziziensis is a viable option for biomass production in no tillage agricultural system, even in denser soils.

The reduction in the number of leaves and the plant height was linearly observed with reduction on spacing between the leaf sheaths along with the pseudostem and the ability to produce leaves (Fig. $1 \mathrm{~B}$ and C). This characteristic demonstrates that plants that grow in soil layers with higher density have the sharp reduction on height and consequently on the leaf emergence as a stress indicator. This observation is explained by the restriction on water and nutrients absorption by the roots as there is an increase in the soil density. The tissue growth involves cell division, which is dependent on those factors.

The leaf area of $U$. ruziziensis plants showed a decreasing polynomial linear behavior with significant reduction as the soil density increased. These observations are justified by the sharp reduction in the height and leaf emission capacity by the plants under stress conditions.

By considering the results of $U$. ruziziensis shoot variables, it is possible to assert that in presence of high soil densities the plants establishment may be compromised with the reductions around $50 \%$ in the capacity of biomass production, plant height, leaf emergence and leaf area, compared to the average between 1.0 and $1.6 \mathrm{Mg} \mathrm{m}^{-3}$. Silva et al. (2001) have also studied soil density levels and found a $40 \%$ reduction of the shoots growth for grain sorghum. Moreover, the reduction in the plant development affects the ability of competition with weeds in the area, which is a desirable feature for cover crops in NTS.

\section{Effect of soil density to root}

The results for root development of $U$. ruziziensis plants demonstrated that the roots were not able to break layers with densities from $1.6 \mathrm{Mg} \mathrm{m}^{-3}$ (Fig. $1 \mathrm{E}$ and F). This observation is confirmed by the absence of roots in the layer of 20 to 30 $\mathrm{cm}$ in the densities with 1.6 and $1.8 \mathrm{Mg} \mathrm{m}^{-3}$. Foloni et al. (2003) found the compacted layer with penetration resistance in the range of $1.4 \mathrm{MPa}$, being restrictive to corn root growth, preventing it from depth development. In a study conducted by Santos (2006) in Botucatu, Brazil, the densities of $1.3 \mathrm{Mg}$ $\mathrm{m}^{-3}$ and $1.5 \mathrm{Mg} \mathrm{m}^{-3}$ had an effect on the root growth of millet in Oxissol.

The reduction in the amount and pores diameter of the soil colloids discourage the process of cell division and elongation of new roots tips, causing thickening due to the mechanical restriction and the low oxygen availability for the root respiration process. Thus, the roots that grow in compacted soils are usually flattened, thick and with irregular and tortuous growth (Torres and Saraiva, 1999).

Studies have also reported that the root diameter affects the ability of filling the biopores and developing higher density soils. Nakamoto (2000) found that there is a higher proportion of roots growth in wheat than in corn through compacted soil layers. It is mainly because they have a smaller diameter in relation to the biopore diameter, allowing an easily change of direction when they meet each other, and enabling a greater ability of breaking higher density soils. According to Reinert et al. (2008), the biological pores formation have little effect on the soil decompression, representing less than $3 \%$ of its volume, but is an important path for the water and oxygen profile inlet, reflecting on crop productivity.

The total root dry biomass (TRDB) showed a significant reduction, attested by the decreasing quadratic polynomial behavior (Fig. 1E). It was clear that the presence of 10 to 20 $\mathrm{cm}$ layers with increasing soil density were decisive for the results, once the root system of plants tried to break them to reach the layer of 20 to $30 \mathrm{~cm}$, increasing the water and nutrient rates absorption. These observations are reinforced when it is verified that the 20 to $30 \mathrm{~cm}$ layer was the one with more variation in TRDB, which was just below the layers with different soil densities. These data corroborate to those 
Table 1. Analysis of variance (F values) for dry biomass of shoots and roots, plant height, leaf area and root volume of $U$. ruziziensis submitted to five levels of soil density.

\begin{tabular}{ll}
\hline Source of Variation & Density Levels \\
\hline DBL & $7.21^{*}$ \\
DBS & $20.37^{*}$ \\
SDB & $15.17^{*}$ \\
PH & $6.97^{*}$ \\
NL & $35.99^{*}$ \\
LA & $42.23^{*}$ \\
RDB $0-10 \mathrm{~cm}$ & $12.51^{*}$ \\
RDB $10-20 \mathrm{~cm}$ & $51.01^{*}$ \\
RDB $20-30 \mathrm{~cm}$ & $128.68^{*}$ \\
TRDB & $147.43^{*}$ \\
RV 0-10 cm & $12.73^{*}$ \\
RV $10-20 \mathrm{~cm}$ & $35.16^{*}$ \\
RV $20-30 \mathrm{~cm}$ & $38.19^{*}$ \\
TRV & $38.93^{*}$ \\
\hline
\end{tabular}

DBL: Dry biomass of leaves - DBS: Dry biomass of steam - SDB: Shoot dry biomass - PH: Plant height - NL: Number of leaves - LA: Leaf area - RDB: root dry biomass in 0-10, 10-20 and 20-30 cm deep - TRDB: Total root dry biomass - RV: Root volume in 0-10, 10-20 and 20-30 cm deep - TRV: Total root volume. Significance values of the $\mathrm{F}$ test: $*(\mathrm{p}<0.05)$.
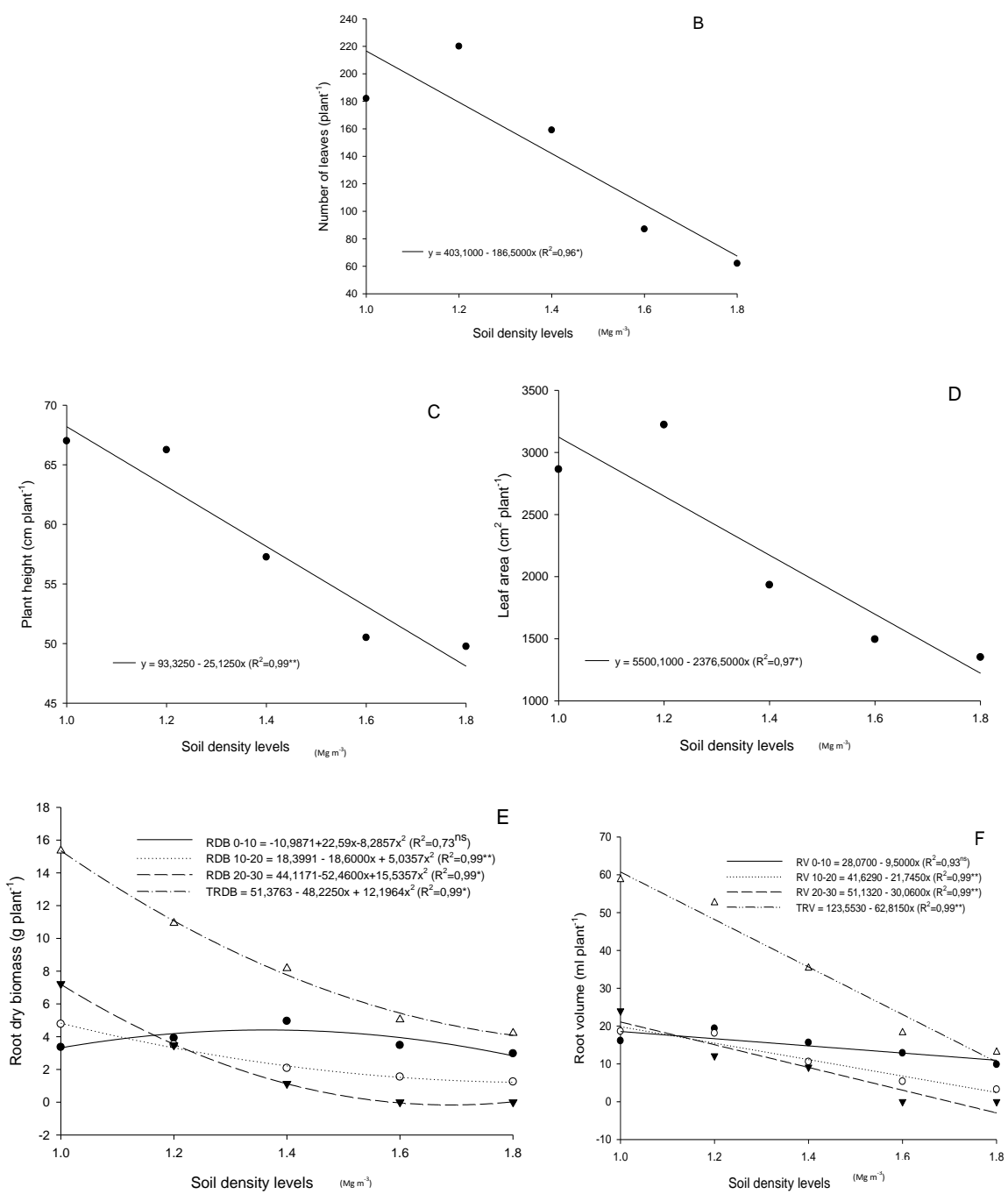

Fig 1. Shoot dry biomass (A), number of leaves (B), plant height (C), leaf area (D), root dry biomass (E) and root volume (F) of $U$. ruziziensis submitted to five levels of soil density in Rondonópolis - MT . Significance values: * and ** significant at 0.05 and 0.01 $\%$ probability and ns: not significant, based on $\mathrm{F}$ test. 
obtained by Pacheco et al. (2015). They demonstrated a significant decrease in root biomass production for Crotalaria spectabilis rings in the soil layer of 10 to $20 \mathrm{~cm}$, whereas below the compacted layer of $20-30 \mathrm{~cm}$ the reduction was even greater.

Bonfim-Silva et al. (2012) observed that there was an increase in the TRDB values of $U$. brizantha as the soil density increased. According to authors, the plants have tried to compensate the higher soil density with the formation of new roots to encourage the absorption of water and nutrients. It is important to note that on this study, the compacted layer was on the top tube, which may have affected the results. Gonçalves et al. (2006) observed that the cover crop know as Eleusine coracana also presented a reduction in TRDB as the soil density increased. In this study, the installation methodology of compacted layers was similar to the present study which may affect the observations related to the ability of the species to develop during the experiment.

The root volume (RV) also presented a linear reduction as the soil density was elevated in the middle layer of the tube $(10$ to $20 \mathrm{~cm})$ (Fig. 1F). The field observations showed that the roots in treatments with higher soil density presented fewer side roots and larger diameter which are symptoms of stress. Calonego et al. (2011b) argued that roots suffer specific morpho-physiological changes of each species to try breaking the soil impedance barrier, reducing their capacity for water and nutrient absorption, causing deficiencies in energy efficiency and biomass production.

From the results obtained, it is clear that the presence of layers with a high soil density in crop systems has a negative effect on the potential development of the $U$. ruziziensis plants. The roots of this species were detected in the dense layer until $1.8 \mathrm{Mg} \mathrm{m}^{-3}$; however, the plant managed to break it up to the density of $1.4 \mathrm{Mg} \mathrm{m}^{-3}$. However, according to Reichert et al. (2007), this root growth below the compacted layer is connected to the soil heterogeneity, with regions of different resistance to the root development, having a high energy consumption that will reflect on the expression of the plants productive potential. By considering that the Oxisol under study comprises the majority of agricultural soils in the Brazilian Cerrado, the studies show that the value of $1.4 \mathrm{Mg}$ $\mathrm{m}^{-3}$ has been restrictive to the crop growth. Silva Nunes (2014) found a soil density of $1.3 \mathrm{Mg} \mathrm{m}^{-3}$ as the limit for the corn development in Oxisol of Rondonopolis-MT.

In no-tillage system (NTS), the roots are concentrated in the 5-15 cm layer; however, some species, with more vigorous root system are able to reach depths greater than 30 $\mathrm{cm}$ (Reichert et al., 2007). We suggest that the $U$. ruziziensis can be used as an attempt to mitigate the effects of possible layers with higher soil density to allow root growth through these layers and, after desiccation and root decomposition, forming channels or biopores can encourage root growth of successive crops.

\section{Materials and Methods}

\section{Experimental area and soil characteristics}

The experiment was conducted in a greenhouse, in northsouth direction, $16^{\circ} 27^{\prime} 50.43$ "S latitude, 54²34'49,39" W longitude , $289 \mathrm{~m}$ of altitude and located in the experimental area of the Institute of Agricultural and Technological Sciences of Universidade Federal de Mato Grosso, Campus Rondonopolis, from August $15^{\text {th }}, 2014$ to February $6^{\text {th }}, 2015$. The study was conducted by a completely randomized design with five treatments and four replications. The treatments consisted in the evaluation of $U$. ruziziensis subjected to five levels of soil density $\left(1.0,1.2,1.4,1.6\right.$ and $\left.1.8 \mathrm{Mg} \mathrm{m}^{-3}\right)$, totally twenty experimental units.

The soil was collected in the native Cerrado area and classified as an Oxisol (Embrapa, 2013). The collection was performed in the layer of 0.05-0.2 $\mathrm{m}$ of depth and the soil passed through a $4 \mathrm{~mm}$ sifted mesh of $4 \mathrm{~mm}$ for ring accommodation for compaction. The chemical characterization and particle size were performed according to Embrapa (1997): $\mathrm{pH}\left(\mathrm{CaCl}_{2}\right)=4.1$; Exchangeable $\mathrm{Al}\left(\mathrm{cmol}_{\mathrm{c}}\right.$ $\left.\mathrm{dm}^{-3}\right)=1.1 ; \mathrm{H}+\mathrm{Al}\left(\mathrm{cmol}_{\mathrm{c}} \mathrm{dm}^{-3}\right)=6.8 ; \mathrm{Ca}\left(\mathrm{cmol}_{\mathrm{c}} \mathrm{dm}^{-3}\right)=$ $0.3 ; \mathrm{Mg}\left(\mathrm{cmol}_{\mathrm{c}} \mathrm{dm}^{-3}\right)=0.2 ; \mathrm{P}$ (Mehlich 1) $\left(\mathrm{Mg} \mathrm{m}^{-3}\right)=2.4 ; \mathrm{K}$ $\left(\mathrm{cmol}_{\mathrm{c}} \mathrm{dm}^{-3}\right)=0.07 ; \mathrm{S}\left(\mathrm{Mg} \mathrm{m}^{-3}\right)=6.8 ;$ Organic matter $\left(\mathrm{g} \mathrm{dm}^{-}\right.$ $\left.{ }^{3}\right)=22.7 ; \mathrm{V}(\%)=6.5$; Clay $\left(\mathrm{g} \mathrm{kg}^{-1}\right)=367$; Sand $\left(\mathrm{g} \mathrm{kg}^{-1}\right)=$ 549; Silt $\left(\mathrm{g} \mathrm{kg}^{-1}\right)=84$.

\section{Experimental conduction}

After collection, the soil was subjected to liming with application of limestone filler (TNP 99.3\%) and incubated for 60 days at $70 \%$ of humidity in plastic bags to raise the base saturation up to $60 \%$. The formulated fertilizer $\mathrm{N}: \mathrm{P}_{2} \mathrm{O}_{5}: \mathrm{K}_{2} \mathrm{O}$ (4-14-8) was applied to $300 \mathrm{Mg} \mathrm{m}^{-3}$ of soil and incorporated into the soil immediately before the experiment installation for all the rings. After that, the planting was conducted with 8 seeds per experimental unit. The experimental units followed the methodology described by Pacheco et al. (2015). Each experimental unit consists of three rings of polyvinyl chloride (PVC) with $150 \mathrm{~mm}$ in diameter and $100 \mathrm{~mm}$ in height. These rings were superposed and joined by adhesive tape (Silver Tape: $48 \mathrm{~mm}$ x $50 \mathrm{~mm}$ ), with the bellow ring supported by an anti aphid screen secured with rubber ring and accommodated in a plastic plates. The upper rings (0-10 $\mathrm{cm}$ ) and below (layer $20-30 \mathrm{~cm}$ ) were filled with soil with a density of $1.0 \mathrm{Mg} \mathrm{m}^{-3}$. The intermediate layer $(10-20 \mathrm{~cm})$ was compacted to obtain the soil density through hydraulic press (Charlott PH5T). Seven days after the emergence, removal of parcels was performed on the remaining three plants per experimental unit. In the first 30 days after sowing (DAS), the irrigation was maintained on the surface of the experimental units and plastic plate to provide appropriate conditions for the plant establishment in the early stages of development. Soil moisture was kept at $70 \%$ of field capacity, using the methodology described by Bonfim-Silva et al. (2011). After this period, irrigation was performed only in the plastic plates (completing the volume twice a day) to stimulate the root growth through the compacted soil layers (Silva et al., 2006). Fourty-eight days after sowing, the experimental variables were quantified. Plant height was determined by a measuring tape $\left(\mathrm{cm}\right.$ plant $\left.^{-1}\right)$. The cutting of the plants was made at soil level to separate the stems and leaves and to determinate the number of leaves (number of leaves perplant) and leaf area $\left(\mathrm{cm}^{2}\right.$ per plant).

\section{Traits measured}

The leaf area was determined through a leaf area meter, Model LI-3100 Area Meter LI-COR Bio-Science. After the measurements, the leaves and stems were taken to air circulation oven of $60{ }^{\circ} \mathrm{C}$ until constant mass to determine dry biomass. Then the root system was washed separately for each PVC ring with soil (upper, intermediate and bellow) to measure the volume and root biomass. The root volume was obtained by a measuring cylinder, where the roots from each depth were dipped into the cylinder that was partially filled with a known volume of water, resulting in the displacement of liquid (Carrigan et al., 1980). The root and leave biomass were obtained by drying the tissues in forced circulation oven 
at $65{ }^{\circ} \mathrm{C}$ for 72 hours, and then were weighed and the data were transformed as g. plant $^{-1}$.

\section{Statistical analysis}

The results were subjected to analysis of variance. After detecting the effect of soil densities for Tukey's test ( $p$ $\leq 0.05$ ), the means were subjected to regression analysis using Sigma Plot 10.0 software (SPSS, Chicago, IL).

\section{Conclusion}

The Urochloa ruziziensis showed reduced plant height, leaf area and number of leaves as soil density increased, resulting in morphological and physiological changes in the plant from densities higher than $1.6 \mathrm{Mg} \mathrm{m}^{-3}$. However, these results demonstrate the ability of this species to break the compacted ground and form biopores. The Oxisols with density value of $1.4 \mathrm{Mg} \mathrm{m}^{-3}$ is restrictive for the plant growth and development.

\section{Acknowledgements}

The acknowledgements are extended to $\mathrm{CNPq}$ (National Council for Scientific and Technological Development) for the scholarships concession to the first, third and fifth authors and to CAPES (Coordination for the Improvement of Higher Education Personnel) for the master's scholarship to the second author.

\section{References}

Bonetti JA, Paulino HB, Souza ED, Carneiro MAC, Silva GN (2015) Influência do sistema integrado de produção agropecuária no solo e na produtividade de soja e braquiária. Pesqui Agropecu Trop. 45:104-112.

Bonfim-Silva EM, Silva TJA, Cabral CEA, Kroth BE, Rezende D (2011) Initial development of grasses under water stress. Rev Caatinga. 24:180-186.

Bonfim-Silva EM, Valadão Júnior DD, Reis RHP, Campos JJ, Scaramuzza WLMP (2012) Establishment of xaraés and marandu grasses under levels of soil compaction. Eng Agríc. 32:727-735.

Calonego JC, Borghi E, Crusciol CAC (2011a) Intervalo hídrico ótimo e compactação do solo com cultivo consorciado de milho e braquiária. Rev Bras Cienc Solo. 35:2183-2190.

Calonego JC, Gomes TC, Santos CH, Tiritan CS (2011b) Desenvolvimento de plantas de cobertura em solo compactado. Biosci J. 27:289-296.

Cardoso EG, Zotarelli L, Piccinin JL, Torres OF, Guimarães MF (2006) Sistema radicular da soja em função da compactação do solo no sistema de plantio direto. Pesqui Agropecu Bras. 41:493-501.

Carrigan L, Frey KJ (1980) Root volumes of Avena species. Crop Sci. 20:407-408.

Collares GL, Reinert, DJ, Reichert JM, Kaiser DR (2008) Compactação de um latossolo induzida pelo tráfego de máquinas e sua relação com o crescimento e produtividade de feijão e trigo. Rev Bras Cienc Solo. 32:933-942.

Dezordi GB, Mendes KF, Macedo GF, Camacho MA, Coletti AJ, Gouveia RGL (2013) Desenvolvimento aéreo e radicular de espécies vegetais em latossolo vermelho distroférrico sob compactação induzida. Sci Plen. 9:1-9.

Empresa brasileira de pesquisa agropecuária (1997) Manual de métodos de análise de solo, Rio de Janeiro. 1997.

Empresa brasileira de pesquisa agropecuária (2013) Sistema brasileiro de classificação de solos. Brasília, 2013.
Foloni JSS, Calonego JC, Lima SL (2003) Efeito da compactação do solo no desenvolvimento aéreo e radicular de cultivares de milho. Pesqui Agropecu Bras. 38:947-953.

Gonçalves WG, Jimenez RL, Araújo Filho JV, Assis RL, Silva GP, Pires FR (2006) Sistema radicular de plantas de cobertura sob compactação do solo. Eng Agríc. 26:67-75.

Homma SK (2005) Efeito do manejo alternativo sobre a descompactação do solo, fungos micorrízicos arbusculares nativos e produção em pomarconvencional de tangor murcott. Dissertação-Mestrado-Piracicaba. 84

Jimenez RL, Gonçalves WG, Filho JVA, Assis RL, Pires FR, Silva GP (2008) Crescimento de plantas de cobertura sob diferentes níveis de compactação em um latossolo vermelho. $\mathrm{R}$ Bras Eng Agríc Amb.12:116-121.

Leonel CL, Centurion MAPC, Centurion JF, Beutler NA, Freddi OS (2007) Relação da compactação do solo com a cultura do amendoim. Biosci J. 23:70-81.

Lima LB, Petter FA, Leandro WM (2015) Desempenho de plantas de cobertura sob níveis de compactação em latossolo vermelho de cerrado. R Bras Eng Agríc Amb. 19:1064-1071.

Nakamoto T (2000) The distribution of wheat and maize roots as influenced by biopores in a subsoil of the kanto loam type. Plant Prod Sci. 3:140-144.

Pacheco LP, São Miguel ASDC, Bonfim-Silva EM, Souza ED, Silva FD (2015) Influência da densidade do solo em atributos da parte aérea e sistema radicular de crotalária. Pesqui Agropecu Trop. 45:464-472.

Passioura, JB (1991) Soil structure and plant growth. Aust J Soil Res. 29:717-728.

Reichert JM, Suzuki LEAS, Reinert JD (2007) Compactação do solo em sistemas agropecuários e florestais: identificação, efeitos, limites críticos e mitigação. Tóp Ci. Solo. 5:49-134.

Reinert DJ, Albuquerque, JA, Reichert JM, Aita C, Andrada MMC (2008) Limites críticos de densidade do solo para o crescimento de raízes de plantas de cobertura em argissolo vermelho. Rev Bras Cienc Solo. 32:1805-1816.

Rosim DC, Maria IC, Silva RL, Silva AP (2012) Compactação de um latossolo vermelho distroférrico com diferentes quantidades e manejos de palha em superfície. Brag. 71:502508.

Sá MAC, Santos Júnior JDG (2005) Compactação do solo: consequências para o crescimento vegetal, Planaltina (2005).

Santos MC. (2006) Desenvolvimento do sistema radicular do milheto (Pennisetum americanum (L.) em duas classes de solo em densidades e diferentes profundidades da camada compactada. Dissertação-Mestrado-Botucatu. 59.

Silva GJ, Maia JCS, Bianchini A (2006) Crescimento da parte aérea de plantas cultivadas em vasos, submetidas a irrigação subsuperficial e a diferentes graus de compactação de um latossolo vermelho-escuro distrófico. Rev Bras Cienc Solo. 30:31-40.

Silva Nunes JA (2014) Desenvolvimento da cultura do milho sob níveis de densidade e tensões de água em Latossolo Vermelho de Cerrado. Dissertação-Mestrado. Universidade Federal de Mato Grosso. 83.

Silva RH, Rosolem CA (2001) Crescimento radicular de espécies utilizadas como cobertura decorrente da compactação do solo. Rev Bras Cienc Solo. 25:253-260.

Soane BD (1990) The role of organic matter in soil compactibility: a review of some practical aspects. Soil Till Res. 16:179-201.

Torres E, Saraiva OF (1999) Camadas de impedimento do solo em sistemas agrícolas com a soja, Londrina. 1999.

Valicheski RR, Brandelero SM, Miquelutti DJ, Stürmer SLK, Tramonti AL, Franzão MC (2016) Absorption of primary macronutrients and soybean growth at different compactation densities and moisture levels in a silt loam soil. R Ceres. 63:223-231 